\title{
Plant communities of the Soutpansberg Arid Northern Bushveld
}

Authors:

Theo H.C. Mostert ${ }^{1}$ George J. Bredenkamp ${ }^{1}$

Rachel E. Mostert ${ }^{2}$

\section{Affiliations:}

${ }^{1}$ Department of Plant

Science, University of

Pretoria, South Africa

${ }^{2}$ Gauteng Department of Agriculture,

Conservation and

Environment, South

Africa

Correspondence to:

Theo H.C. Mostert

e-mail:

karos@ee-sa.com

\section{Postal address:}

African Vegetation and

Plant Diversity Research

Centre, Department of

Plant Science, University

of Pretoria, Pretoria, 0002,

South Africa

Keywords:

phytosociology;

vegetation ecology; arid

savanna; event-driven;

Limpopo Province

\section{Dates:}

Received: 22 Jan. 2009

Accepted: 19 May 2009

Published: 20 June 2009

How to cite this article:

Mostert, T.H.C.,

Bredenkamp, G.J. \&

Mostert, R.E., 2009,

'Plant communities of

the Soutspanberg Arid

Northern Bushveld',

Koedoe 51(1), Art. \#687,

11 pages. DOI: $10.4102 /$

koedoe.v51i1.687

This article is available at:

http://www.koedoe.co.za

(C) 2009. The Authors.

Licensee: OpenJournals

Publishing. This work

is licensed under the

Creative Commons

Attribution License.

\section{ABSTRACT}

The Soutpansberg Arid Northern Bushveld is one of eight major vegetation types (MVT) described for the Soutpansberg-Blouberg region. The plant communities of this MVT are described in detail. Main ecological drivers of the vegetation structure and species composition of these communities are discussed and some conservation recommendations are made. Phytosociological data from a subset of 72 Braun-Blanquet sample plots collected in the Soutpansberg Arid Northern Bushveld were classified using Two-way Indicator Species Analysis (TWINSPAN) and ordinated using a Detrended Correspondence Analysis (DECORANA). The resulting classification was further refined with table-sorting procedures based on the Braun-Blanquet floristic-sociological approach to vegetation classification using the computer software MEGATAB and JUICE. Eight plant communities were identified and described as Commiphora tenuipetiolata-Adansonia digitata short open woodland, Ledebouria ovatifolia-Commiphora mollis short bushland, Phyllanthus reticulatusAcacia nigrescens short bushland, Tinnea rhodesiana-Combretum apiculatum short bushland, Dichrostachys cinerea subsp. africana-Spirostachys africana low thickets, Themeda triandra-Pterocarpus rotundifolius short closed grassland on steep basaltic slopes, Cyperus albostriatus-Syzygium cordatum sandveld wetlands, and Sesamothamnus lugardii-Catophractes alexandri tall sparse shrubland. These plant communities are event-driven ecosystems, predominantly influenced by frequent droughts, exposure to desiccation and unpredictable rainfall events. The complex topography of the Soutpansberg further contributes to the aridity of these ecosystems. The classification and ordination analyses show similar groupings in the vegetation of the Soutpansberg Arid Mountain Bushveld. This confirms the usefulness of complimentary analysis, using both classification and ordination methods on a single data set in order to examine patterns and to search for group structure.

Conservation implications: The results from this study will alter existing regional vegetation maps profoundly. The described plant communities of these arid event-driven ecosystems should be used as benchmark examples of the region's primary vegetation. Conservation and management planning should be based on these vegetation units.

\section{INTRODUCTION}

The arid systems of the Limpopo Province and most of the southern African savannas (Du Plessis 2001; Siebert et al. 2003a) have only been sampled in localised patches, such as in areas of high conservation value or high economic value. Only a few and isolated detailed phytosociological studies have been done on the arid savannas of the Limpopo Province, including those of Breebaart and Deutchlander (1997), Siebert (2001), Du Plessis (2001), Henning (2002), Straub (2002), Götze (2002) and Siebert et al. $(2003 b, 2003 c)$. The vegetation of many areas therefore remains to be investigated and described in order to complete the puzzle of patchy vegetation studies throughout the province. One such an undersampled region is the arid northern bushveld of the Soutpansberg mountain range (Berger et al. 2003). In an overview of the vegetation of the Soutpansberg Conservancy (SC) and the Blouberg Nature Reserve (Mostert et al. 2008), the Adansonia digitata-Acacia nigrescens Soutpansberg Arid Northern Bushveld was identified as a major vegetation type (MVT).

Numerous authors have described different communities and vegetation types of the Soutpansberg Arid Northern Bushveld, such as the Adansonia-Mixed Thornveld (14e) of the Arid Sweet Bushveld (Acocks 1953), the Soutpansberg Arid Mountain Bushveld (11) savanna vegetation type (Van Rooyen \& Bredenkamp 1996a), the Sweet Bushveld (17) savanna vegetation type (Van Rooyen \& Bredenkamp 1996b), the Mixed Bushveld (18) savanna vegetation type (Van Rooyen \& Bredenkamp 1996c), the Colophospermum mopane-Commiphora glandulosa-Seddera capensis open tree savanna in the northernmost section of the Kruger National Park (KNP) (Van Rooyen 1978; Van Rooyen et al. 1981), the CommiphoraTerminalia prunioides community of the Limpopo Plains (Louw 1970), the Ptycholobium contortumColophospermum mopane vegetation type (Du Plessis 2001) and the Soutpansberg Mountain Bushveld (Mucina \& Rutherford 2006). Acocks (1953) mapped the vegetation of this area as Mixed Bushveld (18) on the plain directly north of the Soutpansberg Mountain, Sourish Mixed Bushveld (19) along the northern foot-slopes, and Sour Bushveld (20) south of the northernmost ridges. He described these veld types as 'a Deadalian maze of variations and transitions'. Despite Acocks's valuable efforts and due to the scale of his study, he did not describe the plant communities discussed in this manuscript, and urged that more work had to be done to unravel these complex vegetation patterns. Although not mapped as such, the Adansonia-Mixed Thornveld he described under the heading of Arid Sweet Bushveld may be regarded as a broad and relatively accurate description for the vegetation of the northern plains of the Soutpansberg Conservancy. Van Rooyen and Bredenkamp (1996a) also recognised the uniqueness of this region's vegetation. However, without the necessary data, they too had to lump the extremely diverse vegetation types of the Soutpansberg under the broad term of Soutpansberg Arid Mountain Bushveld. Mucina and Rutherford (2006) erroneously mapped the savanna vegetation of the Soutpansberg Arid Northern Bushveld as Musina Mopane Bushveld and Makhado Sweet Bushveld. However, the general vegetation structure and composition of the Soutpansberg Arid Northern Bushveld is described accurately by Mucina and Rutherford (2006) as a subunit of the Soutpansberg Mountain Bushveld under the heading of 'Arid mountain bushveld'. On a regional scale, this subunit may compare most closely to the Limpopo Sweet Bushveld (Mucina \& Rutherford 2006). 


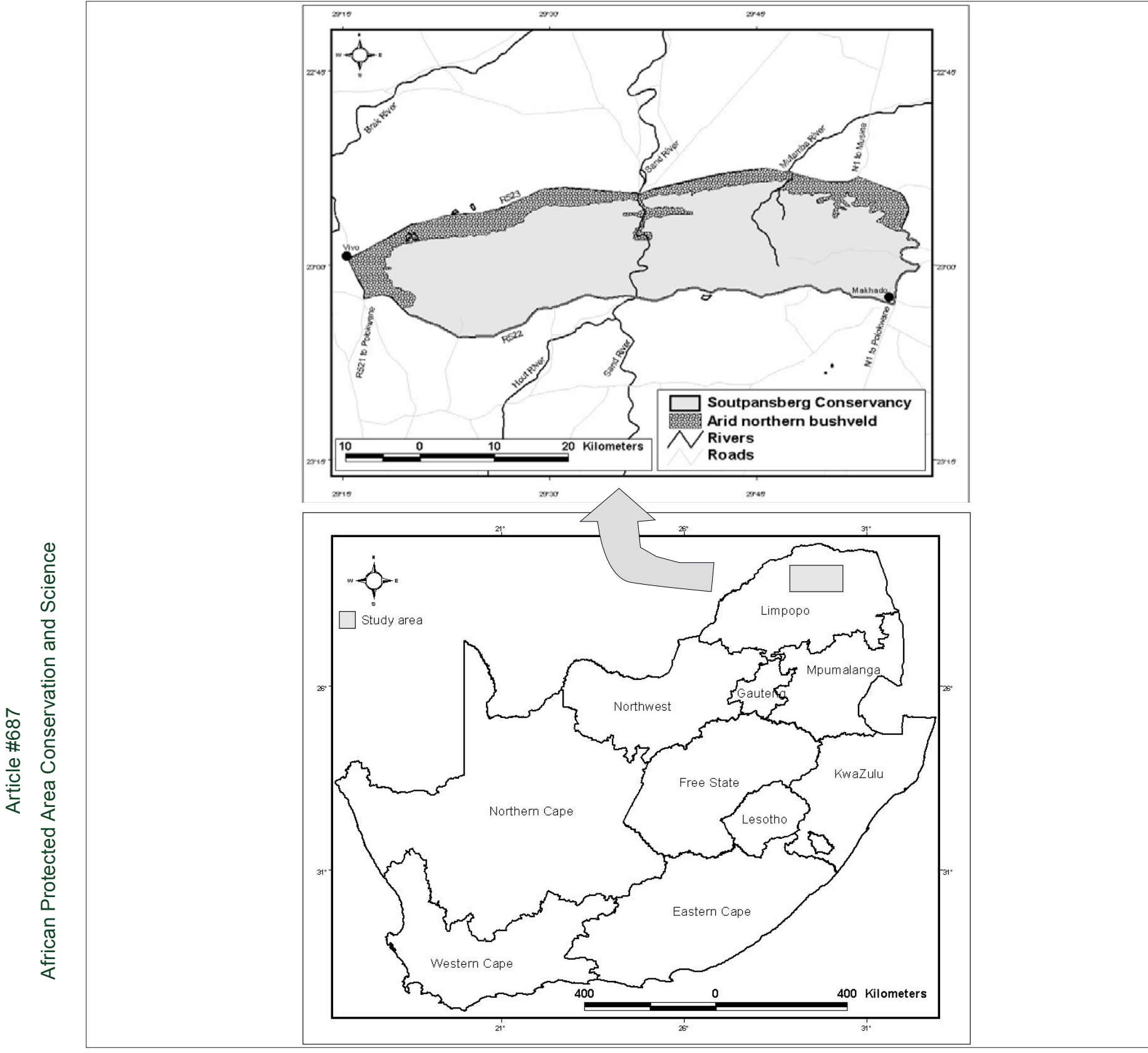

FIGURE 1

ferg Arid Northern Bushveld within the Soutpansberg Conservancy, South Africa

Syntaxonomically, this MVT can be classified under the Commiphoro mollis-Colophospermetea mopani, a class suggested by Winterbach et al. (2000), but not formally described. Although no Colophospermum mopane trees were recorded within this vegetation type during field surveys, numerous species characterising this class and the Adansonia digitataAcacia nigrescens Soutpansberg Arid Northern Bushveld are shared. In a syntaxonomic synthesis of Colophospermum mopane vegetation in southern Africa, Du Plessis (2001) also described this phenomenon, whereby the dominant specie forming part of the name description of a higher-level community within the hierarchical classification is absent from some lower-level communities. Based on the complex of diagnostic species shared by Colophospermum mopane vegetation and the Adansonia digitataAcacia nigrescens Soutpansberg Arid Northern Bushveld MVT, these two vegetation units are synecologically linked.

\section{The study area}

The study area forms part of the Soutpansberg Conservancy (100 $000 \mathrm{ha})$, which is located in the arid northern regions of the Limpopo Province of South Africa (Figure 1). The MVT discussed in this manuscript, the Adansonia digitata-Acacia nigrescens Soutpansberg Arid Northern Bushveld, is confined to the rain-shadow northern ridges of the Soutpansberg (Figure 1). Although its plant communities are associated with a variety of topographic and edaphic conditions, most are adapted to prolonged conditions of water stress and unpredictable rainfall events. This vegetation type includes a variety of arid ecosystems. With the exception of some isolated wetlands dotted along the northern plains, all these communities occur in arid conditions with limited water resources. Water stress within these systems is brought about by both a lack of precipitation, as well as by the unavailability of soil water in the soils of high clay content. The small pore sizes between the soil particles of clay-rich soils create strong adhesive forces with the available water molecules, which inhibit water uptake by hair-roots. The northern foot-slopes have high rock cover, while the lower-lying sandy plains have no surface rocks. The clay content of the soil varies from less than $5 \%$ to more than $55 \%$. The structure of the vegetation can mainly be classified as short open woodland (Edwards 1983). The 


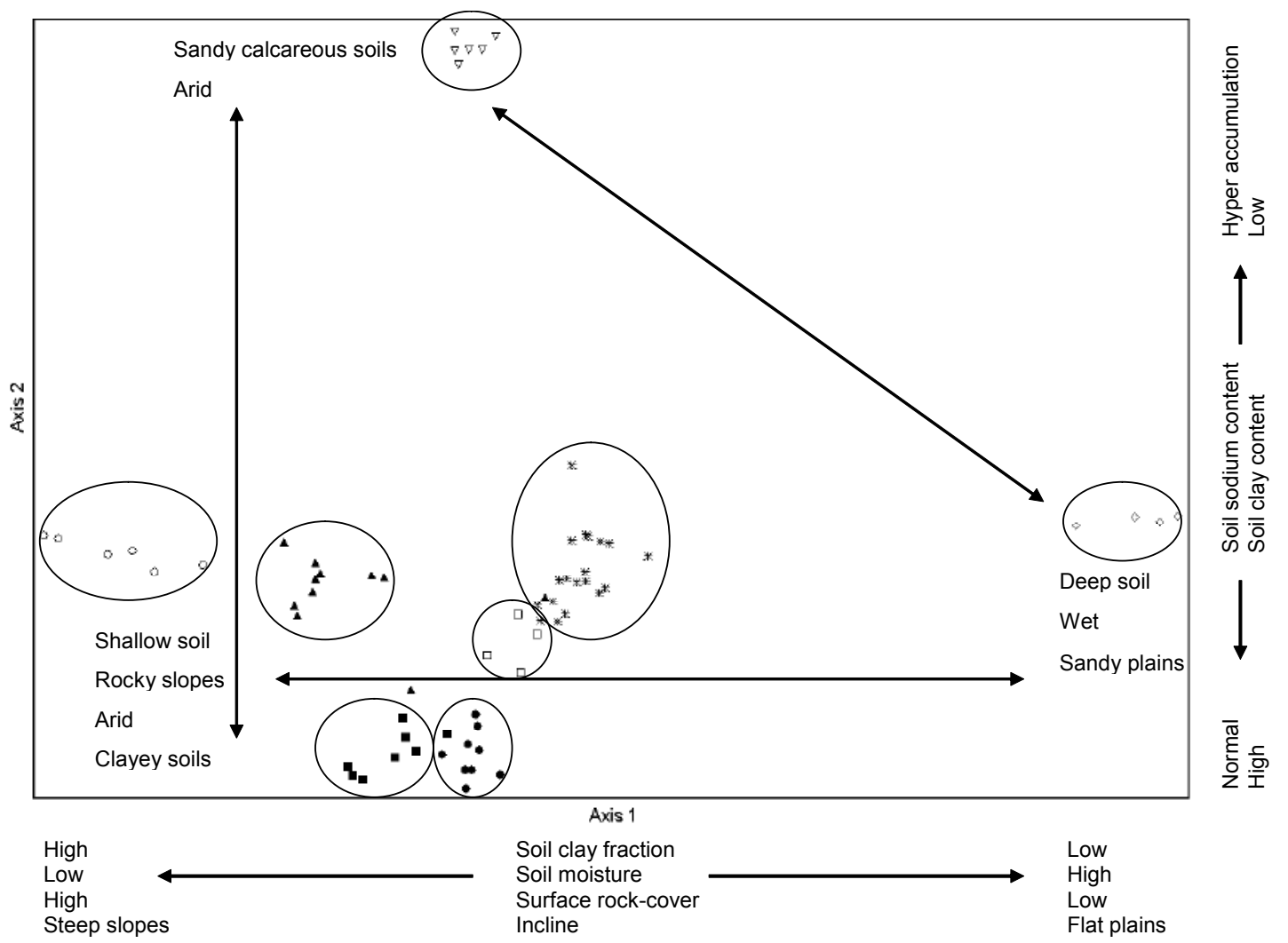

$\nabla \quad$ Sesamothamnus lugardii-Catophractes alexandri tall sparse shrubland

- Tinnea rhodesiana-Combretum apiculatum short bushland

- Ledebouria ovatifolia-Commiphora mollis short bushland

Themeda triandra-Pterocarpus rotundifolius short closed grassland on steep basaltic slopes

- Phyllanthus reticulatus-Acacia nigrescens low-lying short bushland

$\square \quad$ Dichrostachys cinerea subsp. africana-Spirostachys africana low thickets

* Commiphora tenuipetiolata-Adansonia digitata short open woodland

$\diamond \quad$ Cyperus albostriatus-Syzygium cordatum sandveld wetlands

associated terrain includes flat sandy plains, gentle foot-slopes $\left(1\right.$ to $\left.5^{\circ}\right)$ and clayey soil. The exception to this predominantly flat terrain is found in the steep foot-slopes and clayey soil in the deep Sand River Gorge.

This MVT is associated with the Namib soil form (MacVicar, Bennie \& De Villiers 1991) of land types $\mathrm{Ae}, \mathrm{Ag}, \mathrm{Ia}, \mathrm{Ib}$, and Fa derived from sandstone, quartzite and conglomerate of the Wyllies Poort geological formation, and basalt from the Musekwa geological formation as well as from narrow diabase intrusions or dykes within the Wyllies Poort geological formation (Barker 1979, 1983; Botha 2004; Brandl 2002; Patterson \& Ross 2004).

The altitude of the area ranges from approximately $746 \mathrm{~m}$ to 1060 $\mathrm{m}$ above sea level. The average annual rainfall is $382 \mathrm{~mm}$ (South African Weather Bureau 2004), varying between $330 \mathrm{~mm}$ on the farm Omloop to $435 \mathrm{~mm}$ on the farm Sandow. Rainfall events are irregular and localised north of the mountain range.
The Adansonia digitata-Acacia nigrescens Soutpansberg Arid Northern Bushveld MVT, like much of southern Africa's arid and semi-arid areas, is considered to function as event-driven and non-equilibrium ecosystems (Schultze \& McGee 1978; Werger \& Coetzee 1978; Coetzee 1983; Westoby 1979; De Angelis \& Waterhouse 1987; Westoby, Walker \& Noy-Meir 1989; Mentis et al. 1989; Laycock 1991; Behnke \& Scoones 1993; Dodd 1994; Bredenkamp \& Brown 2006). The dynamics of these ecosystems are controlled by external control mechanisms (abiotic factors), which are not subject to feedback control from within the ecosystem (Ellis \& Swift 1988). Climatic factors, such as the irregular and unpredictable droughts, are often the main driving force of arid and semi-arid ecosystems (Noy-Meir 1982; Wiens 1984; Bredenkamp \& Brown 2006).

The aim of this study was to present a first approximation of the plant communities within the Soutpansberg Arid Northern Bushveld MVT, and it can be regarded as a first attempt at understanding the complex ecological patterns and processes observed. It is concerned with the phytosociology of the area's 
vegetation, and aims to identify the different plant communities and to investigate the interrelationships between plant communities and their physical and biological environments. In an attempt to create a holistic image and to explain the macroecology of the region, disciplines such as climatology, geology, pedology, physical geography, history and anthropology are drawn upon and integrated.

\section{METHODS}

Aerial photographs (scale 1:50 000) were used to stratify the study area into physiographic-physiognomic units. A subset of 72 Braun-Blanquet sample plots (each $400 \mathrm{~m}^{2}$ ) was randomly placed within each of these stratified units (Mueller-Dombois \& Ellenberg 1974; Siebert 2001). The taxon names conform to those of Germishuizen and Meyer (2003). Environmental data include soil type, aspect, slope, surface rock cover and disturbance to the soil and vegetation.

The data set was entered into a vegetation database created in Turboveg (Hennekens \& Schamineé 2001) and classified using the polythetic divisive classification algorithm Two-way Indicator Species Analysis (TWINSPAN) (Hill 1979a) within the computer software MEGATAB (Hennekens \& Schamineé 2001) and JUICE (Tichý 2002). Subsequent refinement of the classification was achieved by applying Braun-Blanquet procedures (Bredenkamp, Joubert \& Bezuidenhout 1989; Fuls et al. 1993; Kent \& Coker 1996; Siebert et al. 2003a; Van Staden \& Bredenkamp 2005, 2006). The ordination algorithm DEtrended CORrespondence ANAlysis (DECORANA) (Hill 1979b) was applied using the computer software package PC-ORD (McCune \& Mefford 1999) in order to determine gradients indirectly within the vegetation and infer some relationship between these plant communities and the physical environment. The results are depicted in a scatter diagram.

\section{RESULTS}

\section{Classification}

The analysis of the vegetation data of the Adansonia digitata-Acacia nigrescens Soutpansberg Arid Northern Bushveld MVT resulted in the identification of eight plant communities (Table 1 - online supplement). The first two divisions created by the classification separated the azonal Sesamothamnus lugardii-Catophractes alexandri tall sparse shrubland and the Cyperus albostriatusSyzygium cordatum sandveld wetlands from the remaining zonal communities. A third division separated the grass-dominated slopes of the Themeda triandra-Pterocarpus rotundifolius short closed grassland on steep basaltic slopes from the savanna vegetation. The next division removed the Dichrostachys cinerea subsp. Africana-Spirostachys africana low thickets associated with clay-rich valley bottoms from vegetation on clayey slopes and the arid northern sandy plains communities. A fifth division removed the Commiphora tenuipetiolata-Adansonia digitata short open woodland of the arid northern sandy plains from the remaining communities associated with clayey soils. The sixth division identified in the Tinnea rhodesiana-Combretum apiculatum short bushland, while the last division split the more arid Ledebouria ovatifolia-Commiphora mollis short bushland from the less arid Phyllanthus reticulates-Acacia nigrescens short bushland.

\section{Ordination}

The results of the detrended correspondence analysis are presented in a scatter diagram (Figure 2). This indirect gradient analysis led to the clustering of similar relevés along the first (eigen value $=0.782$ ) and second (eigen value $=0.565$ ) ordination axes. These relevé clusters correspond well with the groups of relevés resulting from the polythetic divisive classification. Environmental gradients represented by the distance along the first and second ordination axes were determined indirectly. The interpretation of these gradients and their possible correlation with environmental factors are dealt with in the discussion section.

\section{DISCUSSION \\ 1. Commiphora tenuipetiolata-Adansonia digitata short open woodland Environmental data}

The vegetation structure of this plant community can be described as short open woodland (Edwards 1983) with large baobab trees breaking the monotone vegetation structure of the landscape. It is found exclusively north of the northernmost ridges of the mountain, where Aeolian (Kalahari) sands have covered the Musekwa sediments at the foot of the mountain. The habitat is flat and marks the beginning of the vast arid Limpopo plain north of the Soutpansberg Mountain. It is mostly confined to the Ia land type, with the Ae land type playing a minor role (Botha 2004). The Hutton soil form (MacVicar et al. 1991) is the dominant soil type. Surface rock cover for this plant community is low.

\section{Diagnostic taxa}

The Commiphora tenuipetiolata-Adansonia digitata short open woodland plant community is characterised by species group A (Table 1). Diagnostic woody species include Sclerocarya birrea subsp. caffra, Commiphora tenuipetiolata, Blepharis subvolubilis and Albizia anthelmintica, with a fair number of Schotia brachypetala associated with termitaria. The herb layer is sparse, with only a few hardy species, including diagnostic species such as Tephrosia macropoda, Ledebouria apertiflora, Hermannia boraginiflora, Dicerocaryum eriocarpum, Chamaecrista mimosoides, Phyllanthus maderaspatensis, Indigofera adenoides, Sansevieria hyacinthoides and Agathisanthemum bojeri. Recorded characteristic grass species include Aristida stipitata subsp. graciliflora and Tricholaena monachne.

\section{Dominant/prominent taxa}

Dominant and prominent woody species include Commiphora tenuipetiolata, Sclerocarya birrea subsp. caffra (species group A), Adansonia digitata, Blepharis diversispina, Combretum mossambicense, Commiphora viminea, Terminalia prunioides, Ximenia americana var. microphylla (species group C), Grewia bicolor (species group F), Acacia nigrescens (species group J), Commiphora glandulosa, Grewia flavescens (species group N), Commiphora mollis, Ximenia caffra var. caffra (species group R), Dichrostachys cinerea subsp. africana, Grewia hexamita, Plectroniella armata, Terminalia sericea (species group U), Acacia tortilis subsp. heteracantha, Boscia foetida subsp. rehmanniana, Commiphora africana, Cordia monoica and Grewia flava (species group Z).

Due to the drought experienced at the time of the field survey, the herbaceous layer was sparse, with only the most droughtresistant perennial species visible and available for collection and identification. This is typical of event-driven systems. None of the recorded forbs could be described as dominant. However, prominent herbaceous species include Blepharis subvolubilis, Chamaecrista mimosoides, Dicerocaryum eriocarpum, Hermannia boraginiflora, Ledebouria apertiflora, Tephrosia macropoda (species group A), Cleome angustifolia subsp. petersiana (species group R), Heliotropium steudneri, Sansevieria aethiopica and Tribulus terrestris (species group Z). Dominant grass species are Aristida stipitata subsp. graciliflora (species group A), Schmidtia pappophoroides and Stipagrostis uniplumis var. uniplumis (species group Z).

Some aspects of the Commiphora tenuipetiolata-Adansonia digitata short open woodland have also been described by Acocks (1953) as the Adansonia-Mixed Thornveld (14e) of the Arid Sweet Bushveld, and by Van Rooyen and Bredenkamp (1996b) as the Sweet Bushveld (17) savanna vegetation type of South Africa. This SC plant community also shares some floristic elements with the Colophospermum mopane-Commiphora glandulosaSeddera capensis open tree savanna in the northernmost section of the KNP (Van Rooyen 1978; Van Rooyen, Theron Grobbelaar 1981). In these plant communities, Adansonia digitata and a variety of Commiphora species contribute greatly 
to the characteristic vegetation structure of open tree savanna. Gertenbach (1983) described this vegetation unit of the KNP as the Adansonia digitata-Colophospermum mopane Rugged Veld. However, in contrast to the Colophospermum mopaneCommiphora glandulosa-Seddera capensis open tree savanna of the northern KNP, the Commiphora tenuipetiolata-Adansonia digitata short open woodland on the sandy plains of the SC is not associated with the rugged basalt koppies and slopes. Louw (1970) described similar vegetation north of the Soutpansberg as the Commiphora-Terminalia prunioides community. However, the Commiphora-Terminalia prunioides community and the Colophospermum mopane-Commiphora glandulosa-Seddera capensis open tree savanna of the northern KNP contain Colophospermum mopane as a strong floristic component. This specie does not occur within the Commiphora tenuipetiolata-Adansonia digitata short open woodland of the SC. Floristic affinities between the above-mentioned plant communities are therefore based on the complex of diagnostic species shared. The Ptycholobium contortum-Colophospermum mopane vegetation type described by Du Plessis (2001) lumps the Commiphora tenuipetiolata-Adansonia digitata short open woodland as part of the Limpopo River Valley Mopane veld north of the Soutpansberg. Straub (2002) described similar vegetation along the Limpopo River Valley as Terminalia prunioides-Colophospermum mopane woodland. These variations of the Mopane veld are associated with arid areas of low and unpredictable annual rainfall (Du Plessis 2001). They are characterised by floristic elements of typically drier habitats, such as Boscia species, Commiphora species, Terminalia prunioides and Adansonia digitata.

\section{Ledebouria ovatifolia-Commiphora mollis short bushland \\ Environmental data}

The vegetation structure of the Ledebouria ovatifolia-Commiphora mollis community can be described as short bushland (Edwards 1983) on arid clayey northern foot-slopes and the northern entrance of the Sand River Gorge of the Soutpansberg. The landscape is very arid, with very little available soil moisture. In times of drought, the field layer dies back dramatically, leaving the soil surface bare and exposed. During such times only the most drought-resistant species remain visible. Due to the frequent occurrence of prolonged droughts and the unpredictability of rainfall events in this area, this event-driven plant community is often suspended in a state of low vegetation cover for long periods of time.

The plant community of the Ledebouria ovatifolia-Commiphora mollis short bushland is restricted to the diabase intrusions in the Wyllies Poort geological formation on the northern foot-slopes of the mountain, and in particular the northern entrance of the Sand River Gorge. The slope of the landscape varies between 5 and $15^{\circ}$. It is associated with the Fa land type and its Glenrosa and Mispah soil forms (Botha 2004; Patterson \& Ross 2004). The soil clay content is high and exceeds an estimated $55 \%$ in some places. Surface rock cover varies between 25 and $50 \%$.

\section{Diagnostic taxa}

This community is characterised by species group B (Table 1). Diagnostic woody species include Dalbergia nitidula, Euclea undulata, Rhigozum obovatum and Pyrostria hystrix. Forbs and succulents recorded and presented in this group are Ledebouria ovatifolia, Asparagus cooperi, Barleria elegans, Ocimum canum, Asparagus racemosus, Abutilon angulatum var. angulatum, Stapelia gigantea, Lantana rugosa and Aloe globuligemma.

\section{Dominant/prominent taxa}

The dominant woody species are all very drought resistant, and include Adansonia digitata (species group C), Terminalia prunioides (species group C), Commiphora marlothii (species group E), Gyrocarpus americanus subsp. africanus (species group E), Lannea schweinfurthii var. stuhlmannii (species group E), Grewia subspathulata (species group F), Combretum apiculatum subsp. apiculatum (species group I), Kirkia acuminata (species group I), Acacia nigrescens (species group J), Maerua edulis (species group $\mathrm{M})$, Grewia flavescens (species group N) and Commiphora mollis (species group R). The field layer is poorly developed. This is especially true at times of below-average rainfall. None of the species recorded within the field layer could be described as prominent.

The Ledebouria ovatifolia-Commiphora mollis short bushland shares numerous floristic links with the Adansonia-Mixed Thornveld (14e) of the Arid Sweet Bushveld (Acocks 1953), the Commiphora-Terminalia prunioides community (Louw 1970), the Colophospermum mopane-Commiphora glandulosa-Seddera capensis open tree savanna in the northernmost section of the KNP (Van Rooyen 1978; Van Rooyen et al. 1981), the Boscio albitruncaeTerminalietum prunioidis (Coetzee 1983), the Adansonia digitataColophospermum mopane Rugged Veld Landscape (Gertenbach 1983), the Sweet Bushveld (17) savanna vegetation type of South Africa (Van Rooyen \& Bredenkamp 1996b) and the Ptycholobium contortum-Colophospermum mopane vegetation type (Du Plessis 2001). The soil of the above-mentioned plant communities might generally be described as extremely arid, shallow and stony with very high clay fractions. Drought-resistant woody species dominate the vegetation structure and composition. The herbaceous layer is poorly developed and unstable due to the unpredictability of rainfall events and the frequent severe droughts in the area. The most prominent diagnostic species shared among these communities are Terminalia prunioides, Adansonia digitata, Boscia albitrunca var. albitrunca, Boscia foetida subsp. rehmanniana, numerous Commiphora species, Sterculia rogersii, numerous Grewia species, Acacia nigrescens and Combretum apiculatum.

Ledebouria ovatifolia-Commiphora mollis short bushland of the northern clayey foot-slopes of the Soutpansberg and Commiphora tenuipetiolata-Adansonia digitata short open woodland of the sandy plains north of the Soutpansberg share strong floristic links through species group C (Table 1).

Several authors have described such communities dominated by Terminalia prunioides, Adansonia digitata, Boscia albitrunca var. albitrunca, Boscia foetida subsp. rehmanniana, numerous Commiphora species, Sterculia rogersii, numerous Grewia species, Acacia nigrescens and Combretum apiculatum (Acocks 1953; Louw 1970; Van Rooyen 1978; Rooyen et al. 1981; Gertenbach 1983; Rooyen \& Bredenkamp 1996b; Du Plessis 2001; Straub 2002). These communities occur predominantly on shallow clayey soil along rocky outcrops, ridges and steep slopes of gorges and rivers that are associated with igneous and intrusive rock formations in semi-arid and arid areas. One of the driving factors seems to be frequent and prolonged water-stressed conditions for vegetation, intensified by the high water-retention capability of clayey soil types (Schultze \& McGee 1978; Werger \& Coetzee 1978; Coetzee 1983; Du Plessis 2001; Bredenkamp \& Brown 2006).

\section{Phyllanthus reticulates-Acacia nigrescens low- lying short bushland Environmental data}

The Phyllanthus reticulatus-Acacia nigrescens low-lying short bushland is located at low altitude ( 800 to $900 \mathrm{~m}$ above sea level) at the southern ends of the north-south-orientated gorges in the east-west-orientated ridges of theSoutpansberg. The vegetation of these gorges, especially that of the continuous Sand River Gorge, shows a strong gradient of declining soil moisture availability from south to north. The varying topography and miscellaneous soil types lead to a very heterogeneous vegetation structure and composition. The shrub and tree layers are well developed and can be regarded as short bushland (Edwards 1983). The field layer is generally poorly developed. This plant community is located within the $\mathrm{Ib}$ and $\mathrm{Fa}$ land types and is associated with Glenrosa and Mispah soil forms (Botha 2004; Patterson \& Ross 
2004). Soil clay content is approximately 35 to $55 \%$. This plant community is restricted to the diabase intrusions within the sandstone and conglomerate of the Wyllies Poort formation, as well as diabase intrusions within the basalt, tuff, sandstone and conglomerate of the Sibasa formation. Surface rock cover varies between 15 and $40 \%$. Due to this community's position within the topography of the mountain's southern slopes, it may receive higher precipitation on a localised scale, especially along the southern extremities of the Sand River Gorge. As moistureladen air is pushed from the south against the sharply rising scarp of the Soutpansberg, it is forced through these ravines and gorges. The venture effect and the rapid cooling of the air lead to the formation of thick mist and fine rain in localised patches (Matthews 1991; Matthews et al. 1991).

\section{Diagnostic taxa}

The plant community of the Phyllanthus reticulates-Acacianigrescens low-lying short bushland is characterised by species group $\mathrm{D}$ (Table 1). The diagnostic woody species of this community include Phyllanthus reticulatus, Ruspolia hypocrateriformis, Wrightia natalensis, Acalypha glabrata, Brachylaena discolor, Canthium mundianum, Pouzolzia mixta, Ruspolia hypocrateriformis var. australis, Clerodendrum makanjanum and Loeseneriella crenata. The grass layer is sparse, with the grass Setaria nigrirostris as the most prominent diagnostic grass species. Diagnostic forbs include Asparagus setaceus, Rhynchosia nervosa, Melhania prostrata and Barleria obtusa.

\section{Dominant/prominent taxa}

A variety of woody species is prominent within this heterogeneous plant community and includes Ruspolia hypocrateriformis, Phyllanthus reticulatus (species group D), Sterculia rogersii, Albizia brevifolia, Entandrophragma caudatum, Markhamia zanzibarica (species group E), Pristimera longipitiolata, Grewia subspathulata, Grewia bicolor, Flueggea virosa subsp. virosa (species group F), Combretum apiculatum subsp. apiculatum, Kirkia acuminata, Ochna inermis, Cassia abbreviata (species group I), Acacia nigrescens (species group J), Brachylaena huillensis (species group L), Grewia flavescens (species group N), Dichrostachys cinerea subsp. africana (species group U) and Hibiscus meyeri (species group Z). Dominant herbaceous species in the field layer include Justicia flava (species group X) and Cissus cornifolia (species group E). The most dominant grass recorded is Setaria nigrirostris (species group D).

The Phyllanthus reticulatus-Acacia nigrescens short bushland, as well as the Commiphora tenuipetiolata-Adansonia digitata short open woodland and Ledebouria ovatifolia-Commiphora mollis short bushland, contain Acacia nigrescens as a prominent species. Based on the prominence of Acacia nigrescens and the general vegetation structure of these communities, some similarities can be seen with the Acacia nigrescens-dominated vegetation types of the southern KNP and the neighbouring reserves to its west (Acocks 1953; Bredenkamp 1982, 1987; Coetzee 1983; Gertenbach 1983, 1987; Bredenkamp \& Theron 1991). The Acacia nigrescensdominated plant communities of the KNP are currently viewed as being part of the Panico maximi-Acacietea tortilis of the Central Bushveld (Winterbach 1998; Winterbach et al. 2000). However, based on the diagnostic species of the Acacia nigrescens-dominated communities within the SC, these communities show stronger floristic links with the Commiphoro mollis-Colophospermetea mopani (Winterbach 1998; Winterbach et al. 2000; Du Plessis 2001). Due to the lack of syntaxonomic work over larger geographical ranges in southern Africa, the correct syntaxonomic position of these three Acacia nigrescens-dominated communities within the SC is not yet clear. Furthermore, depending on whether emphasis is placed on the more persistent woody layer, or whether emphasis is placed on the more dynamic event-driven field layer, the syntaxonomic position of these Acacia nigrescens-dominated communities may change. More vegetation studies investigating the form and function of the herbaceous layer within the eventdriven ecosystems of the southern African savannas with regard to syntaxonomy are sorely needed.
The Phyllanthus reticulatus-Acacia nigrescens short bushland shares very limited floristic links with the Colophospermum mopane-Acacia nigrescens Savanna Landscape of the northern KNP (Gertenbach 1983). The topographic diversity and strong moisture gradients associated with the Phyllanthus reticulatesAcacia nigrescens short bushland of the SC contribute towards the high species richness within the woody layer, compared to the relatively low species richness in woody species associated with the topographically simple north-western KNP (Gertenbach 1983). However, the herbaceous layer of the Colophospermum mopane-Acacia nigrescens Savanna Landscape has a higher species richness than the Phyllanthus reticulates-Acacia nigrescens short bushland with its weakly developed field layer.

\section{Tinnea rhodesiana-Combretum apiculatum short bushland}

Environmental data

The structure of the Tinnea rhodesiana-Combretum apiculatum community can be categorised as short bushland (Edwards 1983). This community is restricted to the rain-shadow northern slopes north of the southernmost ridge of the mountain, but excludes the arid northern slopes of the northernmost ridge of the mountain. It is associated with the clayey soil derived from the basaltic rock of the Musekwa Formation, and falls within the Fa and Ae land types (Botha 2004). The shallow soil is gravelly and littered with talus rock fragments from the broken-up quartzite formations at higher altitude. The top layer of soil is often mixed with sand that has washed down from higher lying quartzite, resulting in soil clay content of between 20 and 35\%. The dominant soil forms are Glenrosa and Mispah.

\section{Diagnostic taxa}

The Tinnea rhodesiana-Combretum apiculatum short bushland community is characterised by the diagnostic species presented in species group $\mathrm{G}$ (Table 1). Some of the woody species in this group include Tinnea rhodesiana, Steganotaenia araliacea, Aloe marlothii subsp. marlothii and Euphorbia ingens. Diagnostic species from the field layer include Barleria ovata, Asparagus bechuanicus and Crabbea velutina.

\section{Dominant/prominent taxa}

Prominent woody species within this plant community include Tinnea rhodesiana, Steganotaenia araliacea (species group G), Combretum apiculatum subsp. apiculatum, Kirkia acuminata (species group I), Maerua parvifolia (species group J) Commiphora glandulosa, Grewia flavescens, Grewia villosa (species group N), Grewia monticola, Commiphora mollis (species group R) and Dichrostachys cinerea subsp. africana (species group U). Due to the dense canopy cover provided by the trees and shrubs, the field layer of this community is poorly developed. The field layer is generally sparse with some patchy stands of grass cover. These stands are either dominated by Enneapogon cenchroides (species group Q) or by a mixture of Heteropogon contortus (species group $\mathrm{L}$ ) and Panicum maximum (species group N).

Within the context of the Soutpansberg, the floristic analyses resulted in this plant community being placed under the Soutpansberg Arid Northern Bushveld MVT. However, the Tinnea rhodesiana-Combretum apiculatum short bushland shares many of the diagnostic and dominant species of the Terminalio sericeae-Combretetea apiculati described by Winterbach et al. (2000) as part of the Central Bushveld savanna classes. It is therefore proposed that the Tinnea rhodesiana-Combretum apiculatum short bushland be classified as part of the Terminalio sericeae-Combretetea apiculati. However, this vegetation class is complex, sharing many floristic elements with the Englerophyto magalismontaniAcacietum caffrae (Winterbach 1998; Winterbach et al. 2000). Due to the topographic and geological diversity associated with these two vegetation classes, plant community turnover on a spatial scale is rapid. This results in mosaic vegetation patterns along the ever-changing environmental gradients. More phytosociological 
and syntaxonomical studies are needed in order to define the status and syntaxonomic positions of the mountain Bushveld and Combretum apiculatum-dominated plant communities of southern Africa. The Tinneo rhodesianae-Combretetum apiculati shows some weak floristic links with the Enneapogono scoparii-Acacietum leiorachis described by Siebert (2001) and Siebert et al. (2003c) as part of the Open Mountain Bushveld of the Sekhukhuneland Centre of Endemism. It also shares some floristic links with the Kirkia acuminate-Colophospermum mopane woodland community located in the Limpopo River valley (Straub 2002).

\section{Dichrostachys cinerea subsp. Africana- Spirostachys africana low thickets \\ Environmental data}

The structure of this plant community can be described as a low thicket (Edwards 1983). It is associated with very finely textured clayey alluvial soils in narrow valley bottoms. All of these valley bottoms are also associated with diabase dykes within the Ae310 land type of the surrounding quartzitic Wyllies Poort geological formation. Soil clay content exceeds $55 \%$, and surface rock cover is negligibly low. Due to the amount of sand washed into and mixed with the clay, the soil is non-vertic, with the Mayo soil form dominating within this section of the landscape. The species of this community are prone to water stress due to the strong water-retention capabilities of the clayey soils. Due to the very palatable grazing and browsing produced by this community during the wet season, the vegetation is frequently over-utilised and trampled by herbivore species. The veld is severely degraded and shows many signs of bush encroachment and thickening.

\section{Diagnostic taxa}

The plant community of the Dichrostachys cinerea subsp. africanaSpirostachys africana low thickets is characterised by the species presented in species group $\mathrm{K}$ (Table 1 ). The only strong indicator specie within this group is Spirostachys africana. The field layer is weakly developed, with only a few uncharacteristic annual species present.

\section{Dominant/prominent taxa}

The woody layer dominates this plant community and consists of drought-resistant species such as Spirostachys africana (species group K), Albizia harveyi (species group L), Maerua edulis (species group M), Balanites maughamii, Boscia albitrunca var. albitrunca, Euclea divinorum (species group $\mathrm{N}$ ), Combretum hereroense (species group P), Commiphora mollis, Grewia monticola (species group R), Dichrostachys cinerea subsp. africana (species group U) and Ehretia rigida (species group Z). The grass Panicum maximum (species group $\mathrm{N}$ ) is the most dominant species in the field layer. Due to the relatively high palatability of the field layer on these nutrient-rich clayey soils, compared to their relatively unpalatable surroundings within the SC, the Dichrostachys cinerea subsp. Africana-Spirostachys africana low thickets are regularly over-utilised by grazers and browsers. This over-utilisation gives the woody layer the competitive advantage above the field layer, resulting in the thickening of the woody stratum and a dominant woody layer (Bredenkamp 1986).

The Dichrostachys-Acacia veld (14g) (Acocks 1953), the Spirostachys africana-Sporobolus ioclados woodland on granite (Van Der Meulen 1979), the Acacia tortilis-Spirostachys africana Savanna community (Bredenkamp \& Van Vuuren 1977), the bottomlands of the thickets of the Sabie and Crocodile Rivers landscape (Gertenbach 1983), the Spirostachys africana-Acacia welwitschii tree and bushveld along sodic drainage lines (Coetzee 1983) and the Euclea divinorum-Acacia welwitschii plant community (Gertenbach 1987) share some floristic links with the Dichrostachys cinerea subsp. africana-Spirostachys africana low thickets of the SC. Due to the over-utilised and bush-encroached nature of the Dichrostachys cinerea subsp. africana-Spirostachys africana low thickets, the woody layer is dominated by the pioneering woody specie Dichrostachys cinerea subsp. africana. The Dichrostachys cinerea subsp. africana-Spirostachys africana low thickets of the SC should be classified under the Spirostacho africanae-Acacion tortilis, as part of the Sporobolo nitentis-Acaciatalia tortilis within the Acacienea nilotico-tortilis of the Panico maximi-Acacietea tortilis described by Winterbach et al. (2000).

\section{Themeda triandra-Pterocarpus rotundifolius short closed grassland on steep basaltic slopes Environmental data}

The Themeda triandra-Pterocarpus rotundifolius community can be described structurally as short, closed grassland (Edwards 1983). It is very restricted within the range of the study area and is associated with a steep section of basalt of the Sibasa formation of the Soutpansberg Group on one of the inner or middle ridges of the mountain. The shallow soil has a clay content of 20 to $35 \%$, surface rock cover of 10 to $25 \%$, and the terrain has an incline of 20 to $30^{\circ}$. Although Botha (2004) classified the area as the Fa land type of the Wyllies Poort geological formation, this basaltic island of the Sibasa formation is atypical of its surroundings. It is associated with the Mayo and Mispah soil forms.

\section{Diagnostic taxa}

The Themeda triandra-Pterocarpus rotundifolius plant community is characterised by the species presented in species group $\mathrm{O}$ (Table 1). Due to the poorly developed woody layer, none of the woody species in species group $\mathrm{O}$ can be described as dominant. These woody species include Acacia caffra, Acacia gerrardii var. gerrardii, Bolusanthus speciosus, Dombeya rotundifolia var. rotundifolia, Gymnosporia buxifolia, Lannea discolor and Pterocarpus rotundifolius subsp. rotundifolius. Diagnostic species within the field layer include the grass species Themeda triandra and the herbaceous species Cleome gynandra, Indigofera hilaris, Rhynchosia komatiensis and Rhynchosia venulosa.

\section{Dominant/prominent taxa}

Although none of the trees or shrubs is dominant, the few prominent but scattered woody species include Bolusanthus speciosus, Pterocarpus rotundifolius subsp. rotundifolius (species group O) and Ozoroa paniculosa var. salicina (species group R). The field layer is dominated by the grasses Themeda triandra (species group O) and Enneapogon cenchroides (species group Q). Herbaceous species include Rhynchosia komatiensis, Indigofera hilaris, Cleome gynandra, Rhynchosia venulosa (species group O) and Cleome angustifolia subsp. petersiana (species group R).

The Themeda triandra-Pterocarpus rotundifolius short closed grassland on steep basaltic slopes shares some limited floristic links with the Themeda triandra-Acacia gerrardii association (Bredenkamp 1982), the Sclerocarya caffra-Acacia nigrescensBothriochloa radicans-Themeda triandra-Digitaria eriantha brushveld (Coetzee 1983) and the Themedo triandrae-Acacietum gerrardii (Coetzee 1983) of the Mpumalanga Lowveld. The soil properties of both these plant communities are typically derived from dolerite and basalt rock, which weather to heavy, poorly drained clayey soils. The limited rainfall associated with these plant communities and the high water-retention capabilities of the clay soils create extremely arid growing conditions for the plant species involved (Werger \& Coetzee 1978; Coetzee 1983; Westoby 1979; Westoby et al. 1989; Mentis et al. 1989; Behnke \& Scoones 1993; Bredenkamp \& Brown 2006). The vegetation structure of such plant communities is typically a dense grass sward with scattered dwarf shrubs.

\section{Cyperus albostriatus-Syzygium cordatum sandveld wetlands Environmental data}

Isolated wetlands are dotted along fault scarps on the northern boundaries of resistant Soutpansberg group quartzite (Scott 1982). At these localities, underground water filters to the 
surface to form 'seepage springs'. The springs are situated within the Ia land type (Botha 2004), which is associated with deep, undifferentiated deposits of scree and sand from the Quaternary System. These isolated swamps differ markedly from their surroundings and may be regarded as azonal plant communities. The vegetation structure varies according to the level of submergence. Along the open water edge, a dense fringe of sedges and water-tolerant grass species grow. The interspersed islands and tongues of higher ground and peat house a tall forest vegetation structure (Edwards 1983) and have been described as swamp forest (Scott 1982).

\section{Diagnostic taxa}

The Cyperus albostriatus-Syzygium cordatum sandveld wetlands are characterised by the diagnostic species presented in species group $\mathrm{S}$ (Table 1). The diagnostic woody species include Syzygium cordatum, Hyphaene petersiana, Acacia robusta subsp. robusta, Senna petersiana, Garcinia livingstonei, Albizia versicolor Mystroxylon aethiopicum subsp. schlechteri, Bridelia mollis, Artabotrys brachypetalus, Ficus sycomorus, Xanthocercis zambesiaca and Hypericum lalandii. Diagnostic grass species are Cynodon dactylon, Andropogon eucomus and Urochloa mosambicensis. Diagnostic sedges, forbs and ferns of this group are Cyperus albostriatus, Thelypteris madagascariensis, Persicaria serrulata, Fimbristylis complanata, Pycreus polystachyos, Fuirena pubescens, Cyperus distans, Wahlenbergia grandiflora, Cyperus solidus and Vernonia centaureoides.

\section{Dominant/prominent taxa}

Dominant tree and shrub species of the Cyperus albostriatusSyzygium cordatum plant community are Syzygium cordatum, Hyphaene petersiana, Acacia robusta subsp. clavigera, Garcinia livingstonei, Senna petersiana, Albizia versicolor, Mystroxylon aethiopicum subsp. schlechteri, Bridelia mollis, Artabotrys brachypetalus, Ficus sycomorus, Xanthocercis zambesiaca (species group S), Philenoptera violacea (species group T) and Grewia hexamita (species group U). The grasses Andropogon eucomus (species group S) and Cynodon dactylon (species group S) were recorded as the most dominant grasses. The four most dominant sedges and ferns are Cyperus albostriatus, Fimbristylis complanata, Fuirena pubescens, Pycreus polystachyos and Thelypteris madagascariensis (species group S).

The Cyperus albostriatus-Syzygium cordatum sandveld wetlands share strong floristic links with the Acacia albida-Ficus sycomorus river/fountain forests of the northern KNP (Van Rooyen 1978; Van Rooyen et al. 1981). These plant communities are driven and maintained by the perennially flooded conditions of sandy soils. Tall hydrophilic tree species dominate the woody vegetation, while sedges and water-tolerant grass species dominate the inundated forest fringes.

The Syzygyium cordatum-Stenoclaena tenuifolia swamp forest, the Ficus trichopoda-Nephrolepis biserrata swamp forest and the Barrintonia acemosa-Bridelia micrantha swamp forests of the Mfabeni peat swamps in St. Lucia (Venter 2003) show only limited floristic links with the woody component of the Cyperus albostriatus-Syzygium cordatum sandveld wetlands of the SC. The extent of the Mfabeni peat swamps is far greater than the isolated wetlands of the SC, and is therefore generally richer in swamp species.

The swamp forests of the Natal Coastal Plain Peatland EcoRegion (Marneweck et al. 2001; Grundling \& Grobler 2005) share very limited floristic links with the Cyperus albostriatus-Syzygium cordatum sandveld wetlands of the SC.

The Closed Riverine Woodlands and the Phoenix reclinataSyzygium spp. on termitaria of the Okavango Delta in Botswana (Biggs 1979) share only limited floristic links with the Cyperus albostriatus-Syzygium cordatum sandveld wetlands of the SC. These plant communities all occur along the slightly elevated sandy soils within the surrounding inundated plains. The dominant trees are hydrophilic and very typical of many of southern Africa's low-lying riverine forests and woodlands. The Cyperus albostriatus-Syzygium cordatum sandveld wetlands should therefore be regarded as unique and restricted to the Soutpansberg area.

\section{Sesamothamnus lugardii-Catophractes alexandri tall sparse shrubland Environmental data}

The vegetation of the Sesamothamnus lugardii-Catophractes alexandri community is a tall, sparse shrubland (Edward 1983) associated with the natural vegetation on the periphery of the saltpan at the north-western end of the Soutpansberg mountain range. The saltpan and its surroundings are part of a unique ecosystem within the surrounding landscape. The terrain is concave and is enriched with sodium chloride. This source of table salt has been mined since the end of the 19th century and is still mined for commercial benefit today. Salt is produced from the dry saltpan at two sites on Zoutpan 459 MS, where brines are pumped from a number of boreholes penetrating the underlying Karoo strata. The salt content of the brines is derived from the basal Karoo shales (Madzaringwe formation) by groundwater action. The long history of disturbance, overutilisation and overgrazing around the saltpan has left the vegetation in a degraded state. The sodium-enriched vegetation attracts numerous grazers and browsers. The more common Soutpansberg savanna species show stunted growth forms within this community. An interesting assembly of halophytic plant species is associated with vegetation on the pan's periphery, such as Heliotopium curassavicum, Suaeda fructicosa and Odyssea paucinervis. This plant community is associated with the Clovelly soil form (MacVicar et al. 1991) of the Ae land type derived from sand of the Quaternary System (Botha 2004). The soil drains freely and has a depth of more than $600 \mathrm{~mm}$.

\section{Diagnostic taxa}

The Sesamothamnus lugardii-Catophractes alexandri plant community is characterised by the diagnostic species of species group V (Table 1). Woody species in this group include Catophractes alexandri, Commiphora pyracanthoides, Acacia nebrownii, Sesamothamnus lugardii, Salvadora australis, Acacia senegal var. rostrata, Balanites pedicellaris, Rhigozum zambesiacum, Acacia mellifera subsp. detinens, Boscia foetida subsp. filipes and a Lycium species. Succulents include Euphorbia guerichiana, Aloe littoralis, Pterodiscus species and Kalanchoe brachyloba. The grass layer is heavily over-utilised. Some of the diagnostic grasses are Sporobolus ioclados, Odyssea paucinervis and Aristida meridionalis. Diagnostic herbaceous species include the forbs Ipomoea adenioides, Dicoma species, Kyphocarpa angustifolia, Kleinia longiflora, Solanum coccineum, Becium angustifolium, Vernonia capensis, Hibiscus calyphyllus, Aptosimum lineare, Becium obovatum, Barleria wilmsiana, Tribulus zeyheri subsp. zeyheri, Becium filamentosum, Evolvulus alsinoides and Adenia repanda.

\section{Dominant/prominent taxa}

Dominant woody species include the drought-resistant Acacia mellifera subsp. detinens, Acacia nebrownii, Acacia senegal var. rostrata, Aloe littoralis, Balanites pedicellaris, Boscia foetida ssp. filipes, Catophractes alexandri, Commiphora pyracanthoides, Lycium species, Rhigozum zambesiacum, Salvadora australis (species group V), Commiphora africana and Boscia foetida subsp. rehmanniana (species group Z). Succulents include Euphorbia guerichiana, Kalanchoe brachyloba, Pterodiscus species and Sesamothamnus lugardii (species group V). Dominant grasses include Eragrostis lehmanniana var. lehmanniana and Schmidtia pappophoroides (species group Z). Herbaceous species are dominated by Heliotropium steudneri, Hibiscus meyeri and Sansevieria aethiopica (species group Z).

The Sesamothamnus lugardii-Catophractes alexandri tall sparse shrubland shows some weak floristic links with the Salvadora australis-Colophospermum mopane main woodland community 
(Straub 2002) of the Limpopo River valley and the Salvadora angustifolia floodplains landscape (Gertenbach 1983) of the KNP. These vegetation units are also associated with sodium-rich soils. However, the processes of sodium accumulation within the soils of these plant communities differ radically. The Salvadora australis-Colophospermum mopane main woodland community (Straub 2002) of the Limpopo River valley and the Salvadora angustifolia floodplains landscape (Gertenbach 1983) of the KNP are both driven by flooding events of the nearby river systems, while the Sesamothamnus lugardii-Catophractes alexandri tall sparse shrubland of the SC is not affected by any river system.

The Sesamothamnus lugardii-Catophractes alexandri tall sparse shrubland shares floristic elements with the Eragrostis viscoseColophospermum mopane major plant community of the semi-arid Mopane veld (Du Plessis 2001) as part of the Etosha National Park (Le Roux et al. 1988). Both these vegetation units are prone to severe droughts and are event driven by nature (Du Plessis 2001). While the soils of the Sesamothamnus lugardiiCatophractes alexandri tall sparse shrubland are sodium rich, the soils of the Eragrostis viscose-Colophospermum mopane major plant community are calcareous (Du Plessis 2001; Hahn 2002). Drought-resistant species such as Catophractes alexandri and numerous Commiphora, Acacia and Boscia species dominate the vegetation. Colophospermum mopane, which is the dominant specie within the Eragrostis viscose-Colophospermum mopane major plant community of the Etosha National Park, does not occur in the Sesamothamnus lugardii-Catophractes alexandri tall sparse shrubland of the SC.

\section{Environmental gradients along ordination axes}

The detrended correspondence analysis led to a scatter diagram depicting distinct clusters of relevés along two ordination axes (Figure 2). Groupings of relevés from the ordination correspond closely with groupings of relevés from the numeric classification, strengthening the vegetation classification proposed for the vegetation of the Soutpansberg Arid Mountain Bushveld. The hierarchical divisions resulting from the classification also correspond well with results from the ordination, whereby primary and secondary hierarchical divisions correspond with greater distances between clusters along the ordination axes. The large relative distances between some of the groupings suggest that these vegetation units probably do not belong to a single syntaxonomic class.

The first axis (eigen value $=0.782$ ), displayed along the $\mathrm{x}$-axis in Figure 2, corresponds with gradients in soil texture, soil depth, incline, surface rock cover and, consequently, soil moisture availability. Associations along the left of the scatter diagram are associated with rocky and clayey slopes along the northfacing slopes and northernmost ridges within the rain-shadow regions of the Soutpansberg. These systems are very arid and highly event driven due to unpredictable low rainfall and the high water-retention capabilities of the shallow clayey soils. The rocky slopes lead to high runoff and weak infiltration of the available rainwater. The clay soils further impede water infiltration due to their poor drainage characteristics. Soil depth contributes to this gradient of available soil moisture revealed by the $\mathrm{x}$-axis. The shallow soils associated with the communities to the left pose restrictions on the potential amount of water that can be stored in the given volume of soil. Although clayey soils have greater potential field capacities to store water, the percentage of water available for uptake by the roots is lower than the percentage available from sandy soils (White 1995). The distribution of plant communities along the $\mathrm{x}$-axis is also correlated with a declining surface rock cover from left to right along the axis. Surface rock cover and rockiness within the soil matrix result in many complex interactions with the biota of a given area, such as an increase in rainwater runoff and a reduction in available soil surface, resulting in a subsequent increased amount of rainwater per unit surface area. Surface rock cover and rockiness provide shelter from desiccating elements such as wind and direct radiation, as well as protection against harsh grazing pressures under certain circumstances. Rocks in the soil matrix may hamper root penetration or may increase competition for the available soil and its available nutrients. The various ways in which rockiness and surface rock cover could influence vegetation make accurate ecological interpretations of the observed distribution of communities along the gradient of increasing surface rock cover extremely complex, requiring cautious inferences.

Soil clay fraction decreases to the right of the scatter plot, while the sand fraction increases. At the extreme right of the scatter plot, conditions are dramatically different from those associated with the plant communities along the left. This swamp forest community is associated with permanent wetness and flooded conditions. The soils are deep and sandy along this relatively flat plain. The swamp forest vegetation of the SC is less driven by drought events, and is more representative of the conventional equilibrium models (Tainton \& Hardy 1999). This relatively stable state is maintained by the constant and predictable source of water from the underlying seepage springs.

The second ordination axis (eigen value $=0.565$ ) is displayed along the $y$-axis of the scatter plot. This axis corresponds with gradients in soil texture, soil depth, incline, surface rock cover and, consequently, soil moisture availability. In addition, the soils of the plant community situated at the top of the scatter plot are enriched with sodium. The cluster of plant communities at the bottom left is associated with rocky and clayey slopes along the northern ridges and northern slopes within the rain shadow of the Soutpansberg. These systems are very arid due to unpredictable, low rainfall and the high water-retention capabilities of the shallow clayey soils. These systems are highly event driven. The plant community at the top is associated with the saltpan of the Soutpansberg. The soils are deep, fine-grained sands, with some evidence of a calcareous layer relatively deep below the surface. The terrain is relatively flat, which results in little runoff and good infiltration of the available rainfall. Surface rock cover is low.

\section{CONCLUSION}

The findings of this study have a profound impact on the existing regional vegetation maps and consequently on conservation management for this region. The Soutpansberg Arid Mountain Bushveld MVT represents a narrow band of previously unmapped Arid Sweet Bushveld (Acocks 1953) along the northern footslopes of the Soutpansberg. This region has previously erroneously been mapped as Musina Mopane Bushveld and Makhado Sweet Bushveld. Acocks (1953) described this vegetation more accurately as Adansonia-Mixed Thornveld, but left it unmapped due to scale issues. The plant communities described in this study represent event-driven ecosystems, predominantly influenced by abiotic environmental factors such as frequent droughts, exposure to desiccation and unpredictable rainfall events. The rain shadow along the northern aspects of the east-west-orientated ridges of the Soutpansberg further increase the aridity of these ecosystems. Biotic environmental factors such as grazing and browsing, as well as fire, play only minor roles in determining the species composition and structure of plant communities under natural conditions. However, high artificial stocking rates within these arid systems with their unpredictable rainfall events invariably lead to overgrazing, with dramatic long-term changes in the vegetation.

The described plant communities can be seen as surrogates for the underlying ecosystems. These plant communities should therefore form the basis for conservation and management planning within the SC. Due to the fact that mostly pristine vegetation types were sampled for this study, the plant communities described should be used as a benchmark and as reference examples of undisturbed primary vegetation against which to measure the ecological integrity of similar systems 
within the region. Benchmark sites from these relatively pristine areas should be used as 'reference tools' in this relatively understudied regional ecosystems, where managers and conservationists lack the necessary data for regional comparisons and extrapolations.

The polythetic divisive classification and the detrended correspondence analysis show similar groupings in the vegetation of the Soutpansberg Arid Mountain Bushveld. This demonstrates the usefulness of complementary analysis, using both classification and ordination methods on a single data set in order to examine patterns in vegetation data and to describe robust and well-defined plant communities. The syntaxonomic comparisons made here with similar plant communities and syntaxa of other regions and ecosystems enable vegetation scientists to view and evaluate the newly described plant communities in regional and biome context. Such comparisons are of crucial importance if we want to reap the numerous benefits offered by formal syntaxonomic vegetation classification.

\section{ACKNOWLEDGEMENTS}

We would like to thank the National Research Foundation for funding this project, and all the landowners within the SC and the management of the BNR for access to gather field data. Thank you to Goro Lodge, Lajuma Mountain Retreat, Medike Mountain Reserve and the Soutpansberg Herbarium for accommodation during the fieldwork.

\section{REFERENCES}

Acocks, J.P.H., 1953, 'Veld types of South Africa', Memoirs of the Botanical Survey of South Africa 28, 1-192, (3rd edition with updated names and illustrations published in 1988 as Memoirs of the Botanical Survey of South Africa 57, 1-146).

Barker, O.B., 1979, 'A contribution to the geology of the Soutpansberg Group, Waterberg Supergroup, Northern Transvaal', MSc thesis, University of the Witwatersrand

Barker, O.B., 1983, 'A proposed geotectonic model for the Soutpansberg Group within the Limpopo Mobile Belt, Southern Africa', in W.J. Van Biljon \& J.H. Legg (eds.), The Limpopo Belt, pp. 181-190, Geological Society of South Africa, Johannesburg.

Behnke, R.H. \& Scoones, I., 1993, 'Rethinking range ecology: Implications for rangeland management in Africa', in R.H. Behnke, I. Scoones \& C. Kerven (eds.), Range ecology at disequilibrium, pp. 1-30, Overseas Development Institute, London.

Berger, K., Crafford, E., Gaiger, I., Gaiger, M.J., Hahn, N. \& Macdonald, I., 2003, A first synthesis of the environmental, biological and cultural assets of the Soutpansberg, Leach Printers \& Signs, Makhado.

Biggs, R.C., 1979, 'The ecology of Chief's Island and the adjacent floodplains of the Okavango Delta', MSc thesis, University of Pretoria.

Botha, M.J., 2004, 'Soil mineralogy', in C.N. MacVicar (ed.), Land types of the map: 2228 Alldays. Memoirs on the Agricultural Natural Resources of South Africa, viewed 12 March 2004 from www.arc.agric.za/institutes/iscw/main/maps/htm.

Brandl, G., 2002, The geology of the Alldays area. Explanation, Sheet 2228: Alldays, Council for Geosciences, Pretoria.

Bredenkamp, G.J., 1982, "n Plantekologiese studie van die Manyeleti-wildtuin', DSc dissertation, University of Pretoria

Bredenkamp, G.J., 1986, 'Ecological profiles of potential bush encroacher species in the Manyeleti Game Reserve', South African Journal of Botany 52(1), 53-59.

Bredenkamp, G.J., 1987, 'An overview of the major plant communities of the Manyeleti Game Reserve, Gazankulu, South Africa', Coenoses 2(1), 29-38.

Bredenkamp, G.J. \& Brown, L.R., 2006, 'Vegetation type and dynamics in African savannas', Berichte der Reinhold-TüxenGesellschaft 18, 69-82.
Bredenkamp, G.J. \& Theron, G.K., 1991, 'The Eucleo divinoriAcacietum nigricentis, a new association from the calcareous bottomland clays of the Manyeleti Game Reserve, Eastern Transvaal Lowveld, Gazankulu, South Africa', Vegetatio 93, 119-130.

Bredenkamp, G.J. \& Van Vuuren, D.R.J., 1977, The plant communities below Turfloop Dam, Lebowa, University of the North, Pietersburg.

Bredenkamp, G.J., Joubert, A.F. \& Bezuidenhout, H., 1989, 'A reconnaissance survey of the vegetation of the plains in the Potchefstroom-Fochville-Parys area', South African Journal of Botany 55, 199-206.

Breebaart, L. \& Deutchlander, M., 1997, 'The vegetation types and management units of the Goedverwacht farm in the mixed bushveld of the Northern Province, South Africa', Koedoe 40, 19-33.

Coetzee, B.J., 1983, 'Phytosociology, vegetation structure and landscapes of the Central District, Kruger National Park, South Africa', Dissertationes botanicae 69, 1-456.

De Angelis, D.L. \& Waterhouse, J.C., 1987, 'Equilibrium and non-equilibrium concepts in ecological models', Ecological Monographs 57(1), 1-21.

Dodd, J.L., 1994, 'Desertification and degradation in subSaharan Africa', Bioscience 44(1), 28-34.

Du Plessis, F., 2001, 'A phytosociological synthesis of Mopaneveld', MSc thesis, University of Pretoria.

Edwards, D., 1983, 'A broad-scale structural classification of vegetation for practical purposes', Bothalia 14, 705-712.

Ellis, J.E. \& Swift, D.M., 1988, 'Stability of African pastoral ecosystems: Alternate paradigms and implications for development', Journal of Range Management 41(6), 450-459.

Fuls, E.R., Bredenkamp, G.J., Van Rooyen, N. \& Theron, G.K., 1993, 'The physical environment and major plant communities of the Heilbron-Lindley-Warden-Villiers area, northern Orange Free State', South African Journal of Botany 59, 345-359.

Germishuizen, G. \& Meyer, N.L., 2003, 'Plants of Southern Africa: An annotated checklist', Strelitzia 14, 1-1231.

Gertenbach, W.P.D., 1983, 'Landscapes of the Kruger National Park', Koedoe 26, 9-121.

Gertenbach, W.P.D., 1987, "n Ekologiese studie van die suidelikste Mopaneveld in die Nasionale Krugerwildtuin', DSc dissertation, University of Pretoria.

Götze, A. R., 2002, 'Plant communities and restoration technologies: Vhembe-Dongola National Park', MSc thesis, Potchefstroom University for Christian Higher Education.

Grundling, P.L. \& Grobler, R., 2005, 'Peatlands and mires of South Africa. Stapfia 85, zugleich Kataloge der Oö', Landesmuseen Neue Serie 35, 379-396.

Hahn, N., 2002, 'Endemic flora of the Soutpansberg', MSc thesis, University of Natal.

Hennekens, S.M. \& Schamineé, J.H.J., 2001, 'Turboveg, a comprehensive database management system for vegetation data', Journal of Vegetation Science 12, 589-591.

Henning, B.J., 2002, 'The relevance of ecosystems to ecotourism in the Waterberg Biosphere Reserve', PhD dissertation, University of Pretoria.

Hill, M.O., 1979a, TWINSPAN-a FORTRAN program for arranging multivariate data in an ordered two-way table by classification of individuals and attributes, Cornell University, New York.

Hill, M.O., 1979b, DECORANA - a FORTRAN program for detrended correspondence analysis and reciprocal averaging, Cornell University, New York.

Kent, M. \& Coker, P., 1996, Vegetation description and analysis: A practical approach, John Wiley \& Sons, Chichester.

Laycock, W.A., 1991, 'Stable states and thresholds of range condition on North American rangelands: A viewpoint', Journal of Range Management 44(5), 427-433.

Le Roux, C.J.G., Grunow, J.O., Morris, J.W., Bredenkamp, G.J. \& Scheepers, J.C., 1988, 'A classification of the vegetation of the Etosha National Park', South African Journal of Botany 54(1), 1-10.

Louw, A.J., 1970, 'Mopane veld noord van die Soutpansberg', DSc dissertation, University of Pretoria. 
MacVicar, C.N., Bennie, A.T.P. \& De Villiers, J.M., 1991, Soil classification: A taxonomic system for South Africa, Department of Agricultural Development, Pretoria.

Marneweck, G.C., Grundling, P.L. \& Muller, J.L., 2001, Defining and classification of peat wetland eco-regions in South Africa, Department of Agriculture, Agricultural Research Council, Institute for Soil, Climate and Water, Pretoria.

McCune, B. \& Mefford, M.J., 1999, PC-ORD for Windows. Multivariate analysis of ecological data, version 4.10, Gleneden Beach MjM Software, Oregon.

Matthews, W.S., 1991, 'Phytosociology of the North-eastern Mountain Sourveld', MSc thesis, University of Pretoria.

Matthews, W.S., Bredenkamp, G.J. \& Van Rooyen, N., 1991, 'The grassland-associated vegetation of the Black Reef Quartzite and associated large rocky outcrops in the north-eastern mountain sourveld of the Transvaal Escarpment', South African Journal of Botany 57, 143-150.

McCune, B. \& Mefford, M.J., 1999, PC-ORD for Windows, Multivariate analysis of ecological data, version 4.10, MjM Software, Oregon.

Mentis, M.T., Grossman, D., Hardy, M.B., O'Connor, T.G. \& O'Reagain, P.J., 1989, 'Paradigm shifts in South African range science, management and administration', South African Journal of Science 85, 684-687.

Mostert, T.H.C., Bredenkamp, G.J., Klopper, H.L., Verwey, C., Mostert, R.E. \& Hahn, N., 2008, 'Major vegetation types of the Soutpansberg Conservancy and the Blouberg Nature Reserve, South Africa', Koedoe 50(1), 32-41.

Mucina, L. \& Rutherford, M.C. (eds.), 2006, 'The vegetation of South Africa, Lesotho and Swaziland', Strelitzia 19.

Mueller-Dombois, D. \& Ellenberg, H., 1974, Aims and methods of vegetation ecology, John Wiley \& Sons, New York.

Noy-Meir, I., 1982, 'Stability of plant-herbivore models and possible application to savanna', in B.J. Huntley \& B.H. Walker (eds.), Ecology of tropical savannas, pp. 591-609, Springer-Verlag, Berlin.

Patterson, D.G. \& Ross, P.G., 2004, 'Soil mineralogy', in C.N. MacVicar (ed.), Land types of the map: 2228 Alldays. Memoirs on the Agricultural Natural Resources of South Africa, viewed 2 March 2004, from www.arc.agric.za/institutes/iscw/main/maps/htm.

Schultze, R.E. \& McGee, O.S., 1978, 'Climatic indices and classification in relation to the biogeography of southern Africa', in M.J.A. Werger (ed.), Biogeography and ecology in southern Africa, pp. 19-52, Junk, The Hague.

Scott, L., 1982, 'A 5000-year old polen sequence from the spring deposits in the Bushveld at the north of the Soutpansberg, South Africa', Palaeoecology of Africa and the surrounding islands 14, 45-55.

Siebert, S.J., 2001, 'Vegetation on the ultramafic soils of the Sekhukhuneland Centre of Endemism', PhD dissertation, University of Pretoria.

Siebert, F., Bredenkamp, G.J. \& Siebert, S.J., 2003a, 'A comparison of Mopane vegetation in South Africa, Namibia and Zimbabwe', Bothalia 33(1), 121-134.

Siebert, S.J., Van Wyk, A.E. \& Bredenkamp, G.J., 2003b, 'Vegetation ecology of Sekhukhuneland, South Africa: Kirkia wilmsii-Terminalia prunioides Closed Mountain Bushveld', South African Journal of Botany 68, 497-517.

Siebert, S.J., Van Wyk, A.E., Bredenkamp, G.J. \& Siebert, F., 2003c, 'Vegetation of the rock habitats of the Sekhukhuneland Centre of Plant Endemism, South Africa', Bothalia 33(2), 207-228.

South African Weather Bureau, 2004, South African Weather Service, viewed 9 February 2004, from http://www. weathersa.co.za

Straub, A.F., 2002, 'The vegetation of Breslau Game Farm, Northern Province, South Africa', MSc thesis, University of Pretoria.
Tainton, N.M. \& Hardy, B.M., 1999, 'Introduction to the concepts of development of vegetation', in N.M. Tainton (ed.), Veld management in South Africa, pp. 1-21, University of Natal Press, Pietermaritzburg.

Tichý, L., 2002, 'JUICE, software for vegetation classification', Journal of Vegetation Science 13(3), 451-453.

Van Der Meulen, F., 1979, 'Plant sociology of the western Transvaal Bushveld, South Africa: A syntaxonomic and synegological study', Dissertationes Botanicae 49, 1-192.

Van Rooyen, N., 1978, "n Ekologiese studie van die plantgemeenskappe van die Punda Milia-PafuriWambiyagebied in die Nasionale Krugerwildtuin', MSc thesis, University of Pretoria.

Van Rooyen, N., Theron, G.K. \& Grobbelaar, N., 1981, 'A floristic description and structural analysis of the plant communities of the Punda Milia-Pafuri-Wambia area of the Kruger National Park, Republic of South Africa: 3. The Colophospermum mopane communities', South African Journal of Botany 47(4), 585-626.

Van Rooyen, N. \& Bredenkamp, G.J., 1996a, 'Soutpansberg Arid Mountain Bushveld', in A.B. Low \& A. G. Rebelo (eds.), Vegetation of South Africa, Lesotho and Swaziland, 21, Department of Environmental Affairs and Tourism, Pretoria.

Van Rooyen, N. \& Bredenkamp, G.J., 1996b, 'Sweet Bushveld', in A.B. Low \& A.G. Rebelo (eds.), Vegetation of South Africa, Lesotho and Swaziland, 25, Department of Environmental Affairs and Tourism, Pretoria.

Van Rooyen, N. \& Bredenkamp, G.J., 1996c, 'Mixed Bushveld', in A.B. Low \& A.G. Rebelo (eds.), Vegetation of South Africa, Lesotho and Swaziland, 25, Department of Environmental Affairs and Tourism, Pretoria.

Van Staden, P.J. \& Bredenkamp, G.J., 2005, 'Major plant communities of the Marakele National Park', Koedoe 48(2), 59-70.

Van Staden, P.J. \& Bredenkamp, G.J., 2006, 'A floristic analysis of forest and thicket vegetation of the Marakele National Park', Koedoe 49(1), 15-31.

Venter, C.E., 2003, 'The vegetation ecology of Mfabeni peat swamp, St. Lucia, KwaZulu-Natal', MSc thesis, University of Pretoria.

Werger, M.J.A. \& Coetzee, B.J., 1978, 'The Sudano-Zambesian region', in M.J.A. Werger (ed.), Biogeography and ecology in southern Africa, pp. 231-299, Junk, The Hague.

Westoby, M., 1979, 'Elements of a theory of vegetation dynamics in arid rangelands', Israel Journal of Botany 28, 169-194.

Westoby, M., Walker, B. \& Noy-Meir, I., 1989, 'Opportunistic management for rangelands not at equilibrium', Journal of Rangeland Management 42(4), 266-274.

White, R.E., 1995, Introduction to the principles and practices of soil science, 2nd edn., Blackwell, Oxford.

Wiens, J.A., 1984, 'On understanding a non-equilibrium world: Myth and reality in community patterns and processes', in D.R.Strong, Jr., D. Simberloff, L.G. Abele \& A.B. Thistle (eds.), Ecological communities: Conceptual issues and the evidence, Princeton University Press, New Jersey.

Winterbach, R., 1998, 'A phytosociological synthesis of Acacia tortilis communities in the north-western savanna of South Africa', MSc thesis, University of Pretoria.

Winterbach, R., Bredenkamp, G.J., Deutschlander, M.S. \& Mucina, L., 2000, 'Preliminary syntaxonomic scheme of vegetation classes for the Central Bushveld of South Africa' in P.S. Whyte, L. Mucina, J.S. Leps \& E. Van der Maarel (eds.), Proceedings of the 41st IAVS Symposium, Uppsala, Sweden, 26 July-1 August, 1998, pp. 123-127. 